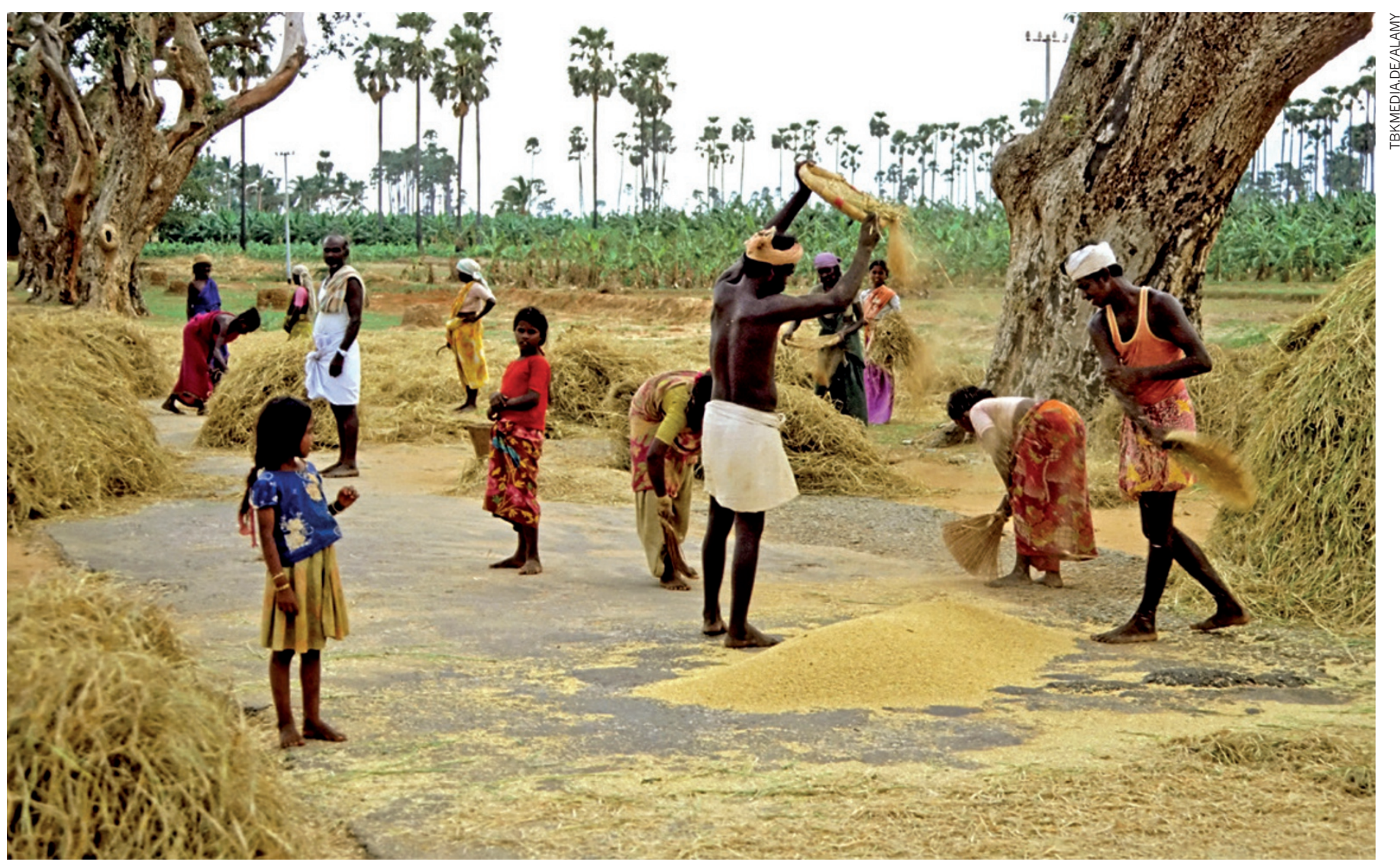

An African community winnowing its rice crop — this ancient farming practice separates the grain from the chaff and helps to remove pests.

AGRICULTURE

\title{
The next frontier
}

\section{Africa's newfound taste for an old grain has experienced problems - drought, low yields and costly imports. But new projects are driving the continent towards self-sufficiency.}

\section{BY KAREN RAVN}

$\mathrm{D}$ iets in Africa are changing. Traditionally, Africans have obtained their carbohydrate calories from maize (corn) and tubers such as cassava and sweet potatoes. But for the past three decades, rice consumption has been on the increase across the continent. "In the 1960s in Burundi, for example, rice was eaten only on feast days," says Joseph Bigirimana, regional coordinator for the International Rice Research Institute in east and southern Africa. "Nowadays, Burundians eat rice every day. And for some families, especially in cities, rice is eaten three times a day." A 2013 report by the International Grains Council, based in London, predicted that over the next five years rice imports would increase in sub-Saharan Africa more rapidly than in any other region in the world.

This newfound taste for rice is understandable, says Gurdev Khush, an agronomist and geneticist at the University of California, Davis. Khush was behind some of the key breeding innovations that helped to ignite the green revolution, an agricultural awakening that brought new strains of rice and farming techniques to Asia in the 1960s. Khush notes that because rice takes much less time to prepare and cook than traditional African standbys such as cassava root, the grain is popular with people who have to cook dinner after a long day at work. Urbanization has also increased the demand for food that can be easily transported and stored. But production is not keeping up with rice's increasing popularity and the continent's growing population, so the gap between supply and demand keeps widening. To fill it, Africa imports a lot of rice, primarily from Asia (see page S50). At the last count, out of 21 million tonnes of rice consumed annually, only about two-thirds -14.5 million tonnes - were home-grown.
Imports made up the 6.5-million-tonne shortfall, at a cost of US $\$ 1.7$ billion.

Closing this gap would have two major benefits for Africa: countries would spend less on rice imports, and the continent would be less vulnerable if the imports stopped or became prohibitively expensive. There is reason to worry about the price of rice. During the global food crisis of 2008 , rice prices quadrupled within just a few months, from less than $\$ 300$ a tonne to more than $\$ 1,200$ a tonne on the world market. Some analysts predict that by 2020 an expanding population and shrinking resources will mean that Asia may no longer have any rice to export and may need to import it instead.

Africa is aiming for self-sufficiency in rice production, but that does not look imminent. "Africa imports a lot of rice and will continue to," says Chris Barrett, director of the Charles H. Dyson School of Applied Economics and Management at Cornell University in Ithaca, 
New York. "That's not going to change in the next five to ten years." What is changing is the way that rice is grown in Nigeria, South Africa, Kenya and other African countries. Scientists and farmers are teaming up to make the crop more sustainable, more productive and more important to Africa's future than ever before. AfricaRice, an independent consortium of 25 rice-producing countries in Africa, is optimistic about the challenge ahead. And, says its director-general Papa Abdoulaye Seck, the "rice sector development can become an engine for economic growth across the continent".

\section{RICE ECONOMICS}

West Africa is the continent's leading riceproducing region, and the countries there are especially bullish about their ability to meet local demands. "Anybody who says Nigeria cannot be self-sufficient in rice production either does not know the country or does not know rice, or both, or is just being mischievous," says Martin Fregene, adviser to the country's agriculture minister, Akinwumi Adesina. If recent trends continue, Fregene predicts that Nigeria could produce enough rice to feed its people by 2016 .

Countries such as Nigeria are taking aggressive economic approaches to encourage rice production - for example, by giving hefty tax breaks to anyone who grows and mills rice locally. In Nigeria, this arrangement has encouraged at least one of its citizens, multibillionaire Aliko Dangote, to ramp up his rice business. In August 2014, Forbes reported that Dangote had invested $\$ 1$ billion in rice production. He has purchased 150,000 hectares of farmland on which he plans to produce 1.4 million tonnes of rice every year, which he will then process in the largest rice mill in Africa - the one he intends to build.

In early 2014, the Bill \& Melinda Gates Foundation in Seattle, Washington, and Germany's Federal Ministry for Economic Cooperation and Development made a different kind of investment in rice by founding the Competitive African Rice Initiative (CARI). This programme will benefit smallholder rice farmers who have a daily income of less than $\$ 2$ by helping them to produce rice that is more competitive in the local marketplace. Among other things, the programme is helping to identify the varieties of rice that are most sought after in the local markets and the facilities that will be required to grow and sell it. "We started with the market and worked our way backwards," says Richard Rogers, senior programme officer at the Gates Foundation.

\section{BETTER YIELDS, BRIGHTER FUTURE}

But encouraging people to grow and process rice is only part of the solution. A more direct approach to increasing rice production is to increase rice yield. And there is plenty of room for improvement in Africa, where the yield is very low, on average 2.2 tonnes per hectare

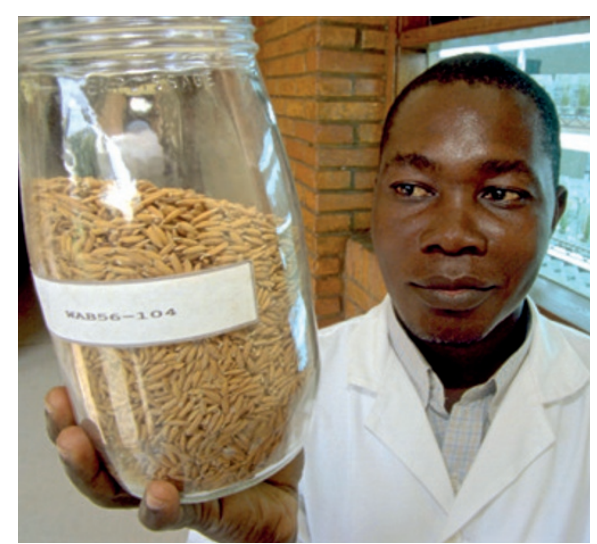

Nerica rice varieties are high yielding and hardy.

- much less than the world average, which is 3.4 tonnes per hectare, and only one-third of the average yield in China, the world's leading rice producer.

Regular and severe drought is one reason for Africa's low yield. Although rice does not have to be submerged in paddy fields to grow well, it does need a lot of water. Irrigation systems are expensive, so about $80 \%$ of farmers rely on rainfall alone. But in most places, there is not enough rain to ensure healthy crops. A study ${ }^{1}$ spanning 1999 to 2003 found that yield for rice grown in rain-dependent lowlands was 2.0 tonnes per hectare, whereas in irrigated lowlands the yield was "Anybody who says Nigeria cannot be selfsufficient in rice production does not know the country, does not know rice, or is being mischievous." $70 \%$ more.

Upland areas might have more rain, but they can lack nitrogen. In some upland areas, the yield is only one tonne per hectare. Fertilizers can supply the needed nitrogen, but many farmers do not have enough money to buy them -

at least in the quantities needed to significantly boost the yield.

In the absence of more money to build irrigation systems or buy fertilizers, the scientific solution is to breed new varieties of rice that need less water and less nitrogen. In fact, this is one of the most promising approaches to solving many of Africa's rice-growing problems.

Only two cultivated species of rice exist. Asian farmers domesticated one of them, Oryza sativa, and a few thousand years later African farmers domesticated the other, Oryza glaberrima (see page S58) ${ }^{2}$. The two species have some traits in common but also significant differences. Crucially, O. sativa produces much higher yields, which gives it more obvious commercial value. It is the species that over the years has come to be grown all over the world. Ever since O. sativa was introduced into Africa, perhaps as early as the 1500 s, O. glaberrima pretty much faded into the bush.

In the process, something was lost.
O. glaberrima is a survivor. It can thrive in harsh conditions that kill its Asian cousin ${ }^{3}$. In the 1990s, plant breeders at AfricaRice decided to try to get some of that hardiness back. They began crossing the two species, hoping to produce a new kind of rice that could be both high-yielding and tolerant. New Rice for Africa, or Nerica, was born.

Nerica is not a single variety of rice but rather a number of different varieties. In general, Nerica strains are high-yielding, producing nearly twice as much per hectare as traditional rice grown in the same conditions. Nerica plants also mature in a hurry, which gives weeds and drought less time to do their damage. Another big benefit is that they have a $25 \%$ higher protein content than the worldmarket average.

Specific Nerica varieties have been developed for various regional conditions. They may be resistant to devastating diseases that are endemic in some areas or to destructive pests that wreak havoc in others. And new varieties are being created all the time. In 2013, for example, the Alliance for a Green Revolution in Africa, a non-profit organization that promotes agriculture on the continent, partnered with the University of Port Harcourt in Nigeria to release three new lowland varieties that were long-grained, high quality and resistant to stresses such as iron toxicity and drought.

In 2005, seven West African countries received funding from the African Development Bank to finance the distribution of Nerica. Farmers chose varieties to grow on the basis of their needs. At the beginning of the project, Nerica strains were being grown on 200,000 hectares across all of sub-Saharan Africa. By 2011, they covered at least 800,000 hectares. Pre-project rice yield was about 1 tonne per hectare in the uplands, but yield now averages 2.5 to 3 times as much. Over the six years of the project, participating farmers earned \$14.4 million more than they would have done otherwise, and the roughly 35,000 members of their households rose above the poverty line of $\$ 1.25$ a day.

Many researchers see parallels between Africa today and Asia in the early 1960s. Asia was then on the brink of a green revolution that improved food security, revitalized economies and stabilized governments. Recreating the Asian green revolution in Africa would be a tall order. But with a combined effort by scientists, farmers, governments and investors, African rice could enter a new era, and history could be repeated.

Karen Ravn is a freelance science writer in Pacific Grove, California.

1. Somando, E. A., Guei, R. G. \& Keya, S. O. (eds) Nerica: The New Rice for Africa - A Compendium Africa Rice Center (2008); see go.nature.com/ wavbxr

2. Wang, M. et al. Nature Genet. 46, 982-988 (2014).

3. Linares, O. Proc. Natl. Acad. Sci. USA 99, 1636016365 (2002) 